\title{
Rhomboid cutaneous flap for defect correction after resection of trichoblastoma on dogs' face
}

\author{
Retalho cutâneo romboide para correção de defeito gerado \\ após ressecção de tricoblastoma em face de cão
}

\author{
Priscilla Bartolomeu de Araújo ${ }^{I}$ Marília de Albuquerque Bonelli ${ }^{I}$ \\ Daniela da Silva Pereira Campinho ${ }^{{ }^{*}}$ José Cláudio de Almeida Souza ${ }^{I I}$ \\ Maria Cristina de Oliveira Cardoso Coelho"II
}

\begin{abstract}
Surgical excision of neoplasms usually requires a large incision with safety margin, resulting in large cutaneous defects. Skin flaps permit closure of extensive cutaneous defects that would not be closed directly. The rhomboid cutaneous flap can be used in places of the body where a rhomboid defect with internal angles of 60 and 120 degrees can be made. The aim of this paper is to report the her use for reconstruction of the defect created after resection of a tumor on dogs'face. Total removal of the tumor and a safety margin was performed, and then the surgical defect was reconstructed with a rhomboid cutaneous flap. The final result was satisfactory, with an esthetically and functional acceptable scar, a without deformities to the oral commissure or eye. The cutaneous flap was considered a viable alternative for reconstruction of large surgical defects, of relatively simple execution and good functional and cosmetic results.
\end{abstract}

- NOTE

do olho. O retalho mostrou-se como uma alternativa viável para reconstrução de grandes defeitos cirúrgicos, de simples execução e com bons resultados funcionais e cosméticos.

Key words: rhomboid, diamond, lozenge, plasty.

RESUMO

Remoção cirúrgica de neoplasias geralmente exige uma excisão ampla com margem de segurança, o que resulta em grandes defeitos cutâneos. Retalhos cutâneos propiciam a possibilidade de fechar defeitos de pele extensos que não seriam fechados por sutura direta. O retalho cutâneo romboide pode ser usado em locais do corpo onde seja possivel a criação de defeito romboide com ângulos internos de 60 e 120 graus. Neste trabalho, relata-se a utilização do referido retalho cutâneo para reconstrução de um defeito cirúrgico gerado após ressecção de tumor em face de cão. Foi realizada a excisão total do tumor com margem de segurança, seguida pela reconstrução do defeito resultante com retalho cutâneo romboide. O resultado final obtido foi satisfatório, com formação de uma cicatriz esteticamente aceitável e funcional, sem deformidades da comissura labial ou Palavras-chave: retalho de Limberg, diamante, losango, plastia,
tricoblastoma.

Skin neoplasias are among the most common in domestic animals and are reportedly the most frequent in dogs (CHALITA et al., 2002). Surgical excision is usually the treatment of choice, which requires the excision of the tumor and free margins of neoplastic cells, which generally results in large skin defects (SAKUMA et al., 2003).

Primary closure of the surgical wound is the best option; however, it may not be possible due to neoplasm location, blood supply, and variation in skin elasticity between individuals and species, for example. Skin flap techniques make the primary closure of surgical wounds possible (DAL-BÓ et al., 2013). In human reconstructive plastic surgery, several techniques are applied with excellent results; however, these are still underused in veterinary practice, either due to cost, or even to a lack of familiarity of the surgeon with the existing techniques (ANGELI et al., 2006; TAVARES et al., 2012; ALVAREZ et al., 2012).

Local flaps are the most practical method to close wounds and cover defects, avoiding

\footnotetext{
'Programa de Pós-graduação em Ciência Veterinária, Universidade Federal Rural de Pernambuco (UFRPE), Rua Dom Manoel de Medeiros, s/n, Dois Irmãos, 52171-900, Recife, PE, Brasil. E-mail: danielacampinho@gmail.com. "Corresponding author.

IInnidade Acadêmica de Garanhuns, Universidade Federal Rural de Pernambuco (UFRPE), Garanhuns, PE, Brasil.

IIIDepartamento de Medicina Veterinária, Universidade Federal Rural de Pernambuco (UFRPE), Recife, PE, Brasil. Received 01.28.15 Approved 10.10.15 Returned by the author 03.23.16 CR-2015-0106.R2
} 
problems associated with second-intention healing (PAVLETIC, 2010). ANGELI et al. (2006) described several types of flaps that can be used in veterinary reconstructive surgeries, among which is the rhomboid cutaneous flap. Created in 1946 by Alexander Limberg, it can be used in several locations for rhomboid defects with internal angles of 60 and 120 degrees. The resulting scars are predictable and generally cause minimal distortion of surrounding structures (ALVAREZ et al., 2012). Skin flap techniques have allowed the primary closure of wounds without fear of being unable to reconstruct local tissues, with fast recovery and a low cost compared with other treatment methods, and with extremely satisfactory cosmetic results.

As such, the objective of the present research is to describe the use of a rhomboid cutaneous flap for the reconstruction of a skin defect originated from tumor excision on a dogs' face, emphasizing the importance of reconstructive surgery in veterinary medicine.

A 7-year-old female dog presented at the Veterinary Hospital of the Federal Rural University of Pernambuco (UFRPE) with a neoplasm on the left lateral region of the face, with a reported evolution of 6 months, measuring approximately $10 \mathrm{~cm}$ in diameter, with a solid consistency on palpation, pedunculated, and with ulcerated areas. A physical exam and diagnostic tests were performed (hemogram; serum measurements of urea, creatinine, alanine aminotransferase, and alkaline phosphatase; thoracic radiographs; and abdominal ultrasound).

No changes were observed on blood work, and no signs of metastasis were found on imaging; and the dog was taken to surgery. Tramadol (5mgkg-1 IV) was given as a preanesthetic medication. Fur was removed from a large area, from the left lateral side of the face to the base of the neck, including the left ventral and lateral region. Anesthetic induction was done with propofol (IV, to effect) and maintenance with isoflurane (inhalant anesthesia).

The dog was positioned on right lateral recumbency, and the perilesional area delimited using a permanent marker (Sharpie ${ }^{\circledR}$ ), in the form of a rhomboid, with approximately $2-\mathrm{cm}$ margins only around the tumor, where the axis with the smaller angle was located longitudinally in relation to the face (Figure 1). The rhomboid cutaneous flap was created at the edge of the defect by extending the smaller axis towards the neck. An incision parallel to one of the sides of the defect was then made, forming an angle of $60^{\circ}$, with a similar length to other sides. Wound closure was then performed by transposition of the flap towards the defect by rotating it by 60 degrees.

Underlying muscles were not included in the flap and particular care was taken during dissection to avoid damage to vascular and nervous structures in the region. The flap was dissected until the muscle plane to permit its complete rotation $\left(60^{\circ}\right)$, and so its extremities could be brought over to the corresponding point of the rhomboid without tension. Stay sutures were placed in each extremity to maintain correct positioning of the flap during closure of the surgical wound. After confirmation of correct flap placement without tension, the skin was sutured (subcutaneous tissue was not sutured) using 4-0 nylon, in simple isolated (more cranial portion) and simple continuous patterns (caudal portion Figure 1). To bandage the wound, micropore tape was placed over the wound and adhered to the skin with the help of a benzoin solution without any medication on the wound. Cephalexin $\left(30 \mathrm{mgkg}^{-1}\right.$ BID PO) for 10 days, tramadol (5 $\mathrm{mgkg}^{-1}$ TID PO) for 3 days, and meloxicam ( $0.1 \mathrm{mgkg}^{-1}$ SID PO) for 5 days, were prescribed, along with an E-collar.

The excised neoplasm was sent for histopathology in $10 \%$ formaldehyde, according to routine institutional procedures. It was classified as a trichoblastoma and surgical margins clear of neoplastic cells were also confirmed.

On the next day, there were no signs of infection or change in the color of the wound edges. The surgical wound was lavaged with saline ( $\mathrm{NaCl} 10.9 \%)$, chlorhexidine, and again saline $(\mathrm{NaCl}$ $0.9 \%$ ) and redressed as previously described. After two weeks, the dog returned for suture removal. There were no complications and the resulting scar was aesthetically acceptable and functional, with no deformities to the canthus of the eye or oral commissure. An oncology follow-up every six months was recommended upon discharge.

Excision of skin neoplasms leads to cutaneous defects that are often difficult to close primarily. Different techniques, such as skin grafts, local or distal flaps, and free skin transfers, can be used (CARDOSO et al., 2011). Skin tumors are among the most frequent in dogs, encompassing approximately one third of all tumors (CHALITA et al., 2002). The tumor histological type in this report, trichoblastoma, is a benign neoplasm, commonly located on the head and neck, that is slow-growing and does not normally metastasize. Complete surgical removal with clear surgical 


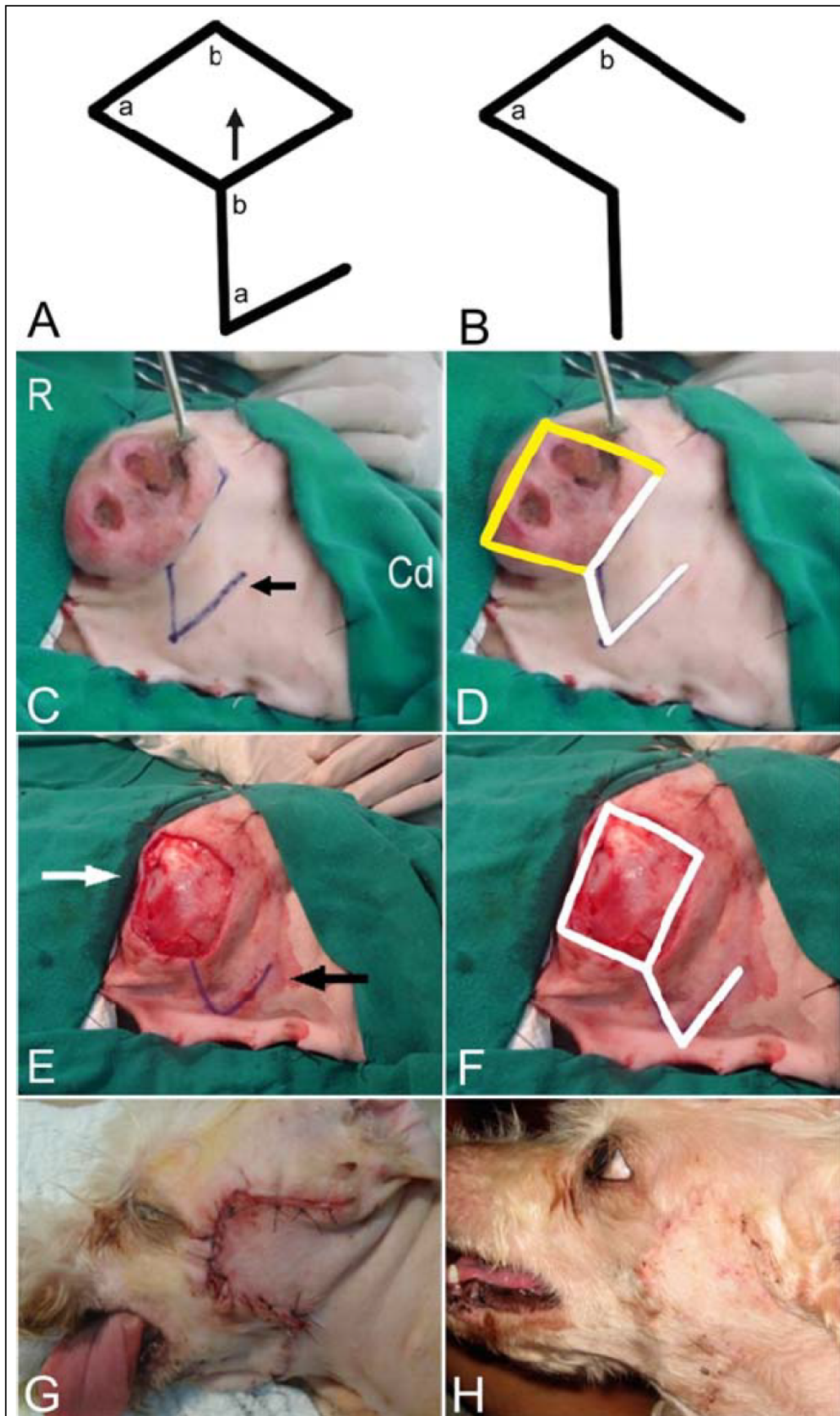

Figure 1 - Drawing representing the rhomboid flap (A). The extremities with the same letter in A are joined during suture of the surgical wound after resection of the neoplasm, resulting in the final form (B). Demarcation of the rhomboid flap (arrow) before resection of the neoplasm. The safety margin, as well as part of the rhomboid cannot be observed in the figure because the base of the neoplasm was smaller than the ulcerated portion held by the Allis forceps (C). Drawing demonstrating the delimitation of the rhomboid; in yellow, the portion not visible in C (D). Surgical wound in a rhomboid shape (white arrow) after removal of the neoplasm. The delineation of the flap that will be used for closure of the wound can be observed (black arrow) (E). Drawing showing the form of the rhomboid as seen in $\mathrm{E}(\mathrm{F})$.,immediately after surgery. The final shape of the flap can be seen, with minimal traction of the skin of the face and resulting tension on the sutures $(G)$. Twelve days after surgery. The final shape of the flap can still be seen, and there is no compromise of the oral commissure or eyelids $(\mathrm{H})$. $\mathrm{R}$ - rostral; $\mathrm{Cd}$ - caudal. 
margins to avoid recurrence is the treatment of choice (GOLDSCHMIDT, 2002). One of the main limitations for reconstructive techniques in oncological surgeries is an incomplete resection, where flaps would increase the area of tumor contamination. This did not occur in the present report, as confirmed by histopathology.

Direct closure of the surgical wound was not possible in the present case. The best alternatives for primary closure would be flaps or skin grafts. When possible, a local flap is probably the most convenient reconstructive technique. The rhomboid flap has good aesthetic results without compromise of function and with preservation of the axial vascular elements of the flap, which increases resistance to infection (CARDOSO et al., 2011). The rhomboid flap is a transposition flap whose technique is simple and can be used in practically any part of the body (ALVAREZ et al., 2012). It was selected in this case due to the ease in its execution and conformation of the type of surgical defect to the proposed flap, as well as other advantages, such as preservation of the original blood supply.

There were no complications during surgery, in creating and transposing the flap, nor in closing the surgical wound. There was also no subsequent facial deformity, which demonstrates how the rhomboid flap can be used in a satisfactory manner to cover defects on the face, with good results (ANDRADE et al., 2012).

One of the difficulties during demarcation of the surgical margins was the size of the neoplasm, which though pedunculated, did not allow a clear view of the entire area. It should be noted that the delimited area suffers changes not only after resection of the tumor and creation of the rhomboid defect, but also from the location of part of the flap on an area of skin loss with great mobility. It is important to consider the location of tension lines since excessive tension during wound suture could result in the compromise of local circulation, delayed healing, wound dehiscence, and skin necrosis (PAVLETIC, 2010).

It is also worth highlighting the importance of preoperative planning and demarcation of the rhomboid-shaped defect and flap to be created before tumor excision, though ALVAREZ et al. (2012) stated that it is not necessary to meticulously follow the measurements to preserve the angles. In previous reports, the defects were adapted to the regions they were being applied to, deforming, at least in part, the rhomboid drawn (ALVAREZ et al., 2012; ANDRADE et al., 2012). In the present report, the rhomboid shape was preserved and attention was given to the form of the flap, equivalence in the size of its corresponding parts, but no measuring tool was used to ensure the precision of the angles.

In the present report, the use of a rhomboid cutaneous flap was of easy execution, low cost, and adequate fur covering, resulting in an excellent aesthetic aspect. From this experience, we would also like to highlight the importance of delimiting the flap so that it can be successfully brought over with a decrease in tension lines, fundamental factors for preserving the viability of the flap.

\section{BIOETHICS AND COMMITTE APPROVAL}

BIOSSECURITY

The authors of the paper entitled "Use of rhomboid cutaneous flap for defect correction after resection of tumor on the face of a dog - Case Report" declare that, as a case report, the procedure that originated the data here reported was not submitted for evaluation by the Ethics Committee of the Universidade Federal Rural de Pernambuco since it did not constitute a project, but we are aware of the content of the resolutions from the National Council for the Control of Animal Experimentation-CONCEA $<$ http://www.mct.gov.br/index.php/content/ view/310553.htm $>$ involving animals.

As such, the authors take full responsibility for the data presented here and are available for possible queries, if that is required by the competent authorities.

\section{REFERENCES}

ALVAREZ, G.S. et al. Aplicação do retalho romboide em reparações cutâneas. Revista Brasileira de Cirurgia Plástica, v.27, n.1, p.102-107, 2012. Available from: <http://dx.doi.org/10.1590/S198351752012000100017>. Accessed: Nov. 07, 2014.

ANDRADE, P. et al. Retalho romboidal duplo para reconstrução de defeito cirúrgico dacomissura labial. Anais Brasileiros de Dermatologia, v.87, n.3, p.456-458, 2012.

ANGELI, A.L. et al. Cirurgia reconstrutiva: retalhos cutâneos em pequenos animais. MEDVEP - Revista Científica de Medicina Veterinária - Pequenos Animais e Animais de Estimação, v.4, n.12, p.87-95, 2006. Available from: <http://dx.doi.org/10.1590/S036505962012000300015>. Accessed: Nov. 07, 2014.

CARDOSO, P.M. et al. Retalho de rotação para fechamento de defeitos cirúrgicos nos dorsos das mãos. Surgical and Cosmetic Dermatology, v.3, n.4, p. 348-349, 2011. Available from: <http://www.redalyc.org/ articulo.oa?id=265522077012>. Accessed: Nov. 07, 2014.

CHALITA, M.C.C. et al. Tumores em pele e partes moles de cães Estudo clínico e cito-histológico. Revista de Educação Continuada CRMV-SP, v.5, p.171-180, 2002. Available from: <http://revistas.bvsvet.org.br/recmvz/article/view/3270>. Accessed: Nov. 07, 2014.

DAL-BÓ, Í.S. et al. Flape cutâneo em padrão axial auricular caudal para correção de defeito extenso após extirpação de 
fibrossarcoma facial em felino. Arquivo Brasileiro de Medicina Veterinária e Zootecnia, v.65, n.6, p.1694-1698, 2013. Available from: <http://dx.doi.org/10.1590/S0102-09352013000600016>. Accessed: Nov. 07, 2014.

GOLDSCHMIDT, M.H. Tumors of the skin and soft tissues. In: MEUTEN, D.J. Tumors in domestic animals. 4.ed. Ames: Iowa State, 2002. p.45-118.

PAVLETIC, M.M. Atlas of small animal wound mangement and reconstructive surgery. 3.ed. Iowa: Wiley-Blackwekk, 2010.696 p.
SAKUMA, C.H.et al. Estudo clínico sobre aplicação do retalho cutâneo pediculado em cirurgia oncológica no cão. Brazilian Journal of Veterinary Research and Animal Science, v.40, supl.1, p.32-37., 2003. Available from: <http://dx.doi.org/10.1590/ S1413-95962003000700005>. Accessed: Nov. 07, 2014.

TAVARES, E. et al. Retalho de avanço V-Y de pedículo proximal para encerramento de defeito cirúrgico do dorso da mão. Revista da Sociedade Portuguesa de Dermatologia e Venereologia, n.70, v.3, p.345-347, 2012. Available from: <http://revista.spdv. com.pt/index.php/spdv/article/view/11>. Accessed: Nov. 07, 2014. 